\title{
INTRATEXTUALIDAD EN EL POEMA "LOS HERALDOS NEGROS" DE CÉSAR VALLEJO, VERSIÓN PRIMERA- VERSIÓN OFICIAL, E INTERTEXTUALIDAD CON EL GRITO DE EDVARD MUNCH
}

\author{
Ronald Campos López
}

\begin{abstract}
RESUMEN
Se pretende analizar las relaciones intratextuales entre la versión primera y la versión oficial del poema "Los heraldos negros" de César Vallejo, a partir de los gramas (fonético, sémico y sintagmático) del texto barroco según Severo Sarduy; así como las relaciones intertextuales de ambos textos con El grito de Edvard Munch, en tanto reminiscencias de una textualidad de perspectiva existencial.

Palabras clave: Intratextualidad, intertextualidad, Vallejo-César, Munch-Edvard, Sarduy-Severo.
\end{abstract}

\begin{abstract}
The aim is to analyze intratextual relations between the first version and the official version of the poem "The Black Heralds" by Cesar Vallejo, based on the phonetic, semic and syntagmatic graphics of the Baroque text according to Severo Sarduy; in addition, the intertextual relations of both texts are compared to "The Scream" by Edvard Munch, as reminiscent of a textuality of existential perspective. Keywords: intratextual, intertextuality, Vallejo-César, Munch-Edvard, Sarduy-Severo.
\end{abstract}

\section{La triple venida de los heraldos}

El poema "Los heraldos negros" de César Vallejo representa un paradigma poético en la literatura latinoamericana. En este, se equilibra el dramatismo de la existencia humana, utilizándose un lenguaje cuya tonalidad pareciera directa en una primera impresión; una transgresión gramatical aliada a una semántica violencia del destino contra el hombre (Paoli 1988). Sin embargo, el

Lic. Ronald Campos López. Profesor. Instituto de Educación Integral, la Universidad Internacional de las Américas.

Correo electrónico: ronaldcl84@yahoo.com

Recepción: 29- 08- 2011

Aceptación: 04- 10- 2011 
máximo desarrollo de esta estancia lírica sucede a partir de la evolución de metáforas continuas, que permiten una ambientalidad y una carga emotiva capaz de envolver a cualquier lector en su corriente de conciencia.

El discurso poético vallejiano se ha estudiado desde distintas perspectivas. Se han observado las correspondencias de lo lírico y la identidad latinoamericana (Chavarría 1988; Oviedo 1990) o con la alteridad (Melis 1988); las revoluciones lingüísticas y retóricas en su poesía (Ly 1988); las significativas temáticas de la muerte (Montiel 1988; Vélez 1988) y el dolor (Montiel 1988); las referencias bíblico-religiosas en la poesía vallejiana, su función crítica (Martínez 1988) y las aproximaciones dialécticas entre sus textos y la religión (Ortega 1988); así como los contextos donde aparece su obra poética (Chirinos 1988; Ferrari 1988; Paoli 1988; Yurkievich 1988).

Particularmente, la versión oficial del poema homónimo al libro aparece publicada en 1919. Sin embargo, la edición de la obra poética de Vallejo, coordinada por Ferrari (1997), recoge el borrador de la primera versión de este poema. A partir de su lectura, surge la inquietud por seguir más de cerca los cambios producidos en las imágenes, adjetivos y núcleos de significado entre una versión y otra. Esto, en resolución, motiva estudiar las relaciones internas de ambos poemas, los cuales, se pensaría, son el mismo, pero con la única e insignificante salvedad de que uno está corregido y es mejor que el otro. Empero, ambos textos son válidos. Resultan manifestaciones independientes, cuya oficialidad fue electa por el autor, el movimiento publicitario y la editorial.

Los heraldos negros se relaciona con situaciones del entorno y momento histórico cuando es publicado; así, sugiere y orienta un paradigma de las lecturas posibles. Entre estas no se escapan la social, la existencial, esa búsqueda que bien ubicaría a esta producción lírica "no en el esteticismo modernista sino en el de la ansiosa indagación por un más allá humano que caracteriza la conciencia moderna, pase ella o no por la experiencia vanguardista" (Oviedo 1990: 253).

Esta temática, cotidiana y trascendental, atraviesa el poemario completo y se sintetiza en el poema homónimo, el cual no por casualidad abre el libro. Puesto que tales textos se publican en una época convulsa, en la cual se problematizan las identidades latinoamericanas y las europeas debido a la Primera Guerra Mundial, por qué no relacionarlos externamente con otros textos. A pesar de la infinitud de posibilidades, en este estudio, se restringirá la comparación con el texto pictórico: El grito (1893), de Edvard Munch, pues este cuadro indaga también, ansiosamente, como afirma Oviedo (1990), por un más allá humano.

El artista expresionista trató de representar la experiencia emocional en su forma más completa, sin preocuparse de la realidad externa, sino de su naturaleza interna y de las emociones que despierta en el observador. Para lograrlo, los temas se exageran y se distorsionan con el fin de intensificar la comunicación artística. La contemplación del mundo, el efecto interno en la consciencia y la hipérbole de esa angustia, como se demostrará, son, también, el eje retórico y subjetivo de "Los heraldos negros".

Ya en otra oportunidad, Juliá (1988) presentó la expresión similar de los sentimientos entre la poesía de Vallejo y los cuadros del pintor noruego. Ambos artistas trabajan los temas de la muerte y su ambigüedad, el desamparo y la vida como "un absurdo incomprensible y horrendo cuyas leyes han sido vedadas al hombre” (Juliá 1988: 98). Ambos utilizan la expresión artística como una necesidad vital de catarsis, pues a Munch: "Como a Vallejo, lo que le interesaba era, nada menos, que mostrar el dolor que sentía en todo" (Juliá 1988: 98). 
Esta autora también expone diferencias entre ambos; a saber: la actitud de uno y otro frente a lo absurdo de la existencia, pues Munch tiende a experimentar dolor y miedo, mientras Vallejo toma este dolor y juega humorística y retóricamente.

Se parte, entonces, hacia el estudio intratextual entre ambas versiones de "Los heraldos negros", respecto de su perspectiva temática, y las posibilidades intertextuales que puedan establecerse con el texto expresionista de Munch, ya que el tono general de los poemas vallejianos, como, en este caso, "Los heraldos negros", produce "una honda sensación de desconsuelo parecida a la sentida en las pinturas de Munch” (Juliá 1988: 101).

\section{Sobre los potros teóricos}

Se trabajará en este análisis, con base en la propuesta teórica de Sarduy (1977) respecto a lo barroco y lo neobarroco en la literatura latinoamericana del siglo XX, donde se detallan los recursos que permiten la intratextualidad e intertextualidad de las prácticas culturales literarias. Asimismo, se enfatizará la noción de texto, con tal de facilitar la comprensión de este término a la hora de establecer los diálogos entre textos poéticos y pictóricos.

\subsection{Intratextualidad}

Sarduy considera la presencia de algunos gramas dentro de cada texto, los cuales se manifiestan como incisos "intrínsecos a la producción escriptural, a la operación de cifraje [...] en que consiste toda escritura" (1977: 178). En otras palabras, no se encuentran sobre la aparente superficie plana de cada texto, a diferencia de aquellos incisos que bien podrían relacionarse intertextualmente con otras producciones, sino que se deslizan desde la escritura entre la escritura misma. Desde esta premisa, Sarduy distingue tres gramas típicos del texto barroco: gramas fonéticos, sémicos y sintagmáticos.

\subsubsection{Gramas fonéticos}

Crean otras posibles unidades de sentido con base en las voces que puedan ser escuchadas. Desde las líneas tipográficas del texto pueden transgredirse los fonemas con tal de otras lecturas radiales. La aliteración como figura de construcción, repetición de un fonema (casi siempre consonántico) o de una sílaba tónica que contribuye a dar estructura rítmica a un verso o a una línea de un escrito en prosa, funciona como mecanismo de énfasis del significado y otorga sonoridad y ritmo. Por lo tanto, si partimos de un posible impulso de la escritura surgido precisamente de la atención que se presenta a los gramas fonéticos, la aliteración como tal parece provocar en nosotros como lectores esas lecturas radiales del significado a partir de los fonemas convocados.

\subsubsection{Gramas sémicos}

Resultan totalmente descifrables bajo la línea del texto, detrás del discurso. No es posible llegar a ellos a partir de la lectura transgresiva de los fonemas. El significado a que se refiere el discurso manifiesto no permite la ascensión de sus significantes a la superficie del texto. Por ello, se habla de un idiom reprimido; es decir, de una detección de la unidad de 
sentido desde una prohibición o exclusión del espacio de la escritura de ciertos semas que el discurso codifica apelando a la figura típica de la perífrasis. Se tendría, pues, como uno de los soportes de la función de encubrimiento la omisión, o más bien la utilización de núcleos de significación tácitos, hacia los que convergen las flechas de los indicadores. La producción simbólica podría atenderse como una de las operaciones perifrásticas del lenguaje, ya que un símbolo designa, significa lo ausente.

\subsubsection{Gramas sintagmáticos}

Se manifiestan en tanto que la lectura corresponde a un encadenamiento de secuencias o en las articulaciones interiores a estas, desciframientos parciales y progresivos que avanzan por contigüidad y nos remite retrospectivamente a su totalidad. Es decir, que un conjunto de materia nebulosa se muestra aglutinada y sostiene un procedimiento de garantía, de pertenencia a una clase constituida, que bien sería el texto y su totalidad. Dicha materia sería la gramática, el código formal, que funciona como soporte artificioso. En consecuencia, las categorías de lectura solo se volverán explícitas a medida que las redes de puntos-eventos van configurando posibles recorridos a través del significado.

\subsection{Intertextualidad}

Sarduy (1977) habla sobre dos modos de incorporación de un texto extranjero en otro, ya sea de manera que no se modifiquen sus elementos, la cual denomina cita; y, por otro lado, de manera reminiscente.

La reminiscencia corresponde a la forma mediata de incorporación en que el texto extranjero se funde al primero, sin implantar las marcas en la superficie, pero sí constituyendo los estratos más profundos del texto receptor, modificando con sus texturas su geología. Por lo tanto, la reminiscencia latente siempre en sí misma determina el tono arcaico del texto visible.

\subsection{Texto}

Según Amoretti, resulta preferible utilizar el término 'textualidad' en vez de 'texto', puesto que aquel incluye no solo el aspecto del lenguaje, sino también el punto de vista social. Dicha autora, con base en la definición de Schmidt sobre textualidad, expone:

\footnotetext{
La textualidad funciona como forma normativa de manifestación y realización del comportamiento social a través de las lenguas, por lo tanto, los textos siempre son verbal y socialmente determinables. La textualidad, entonces, sólo puede ser descrita en el contexto de las relaciones sociales de interacción. (1992: 118)
}

Entiéndase, por tanto, para instancias de este análisis, con el término de 'texto', la connotación de una 'textualidad' a la que se le atribuyen tanto una capacidad de convocar múltiples lenguajes en el acto de su constitución (ya fuese pictórico, musical, gestual o lingüístico), así como el de deconstruirse a partir de asociaciones posibles entre el lenguaje que lo constituye y lo social, dado que, si el texto "permite varios sentidos, una pluralidad de sentidos, no permite cualquier sentido" (Amoretti 1992: 119), sino aquellos que en la inmanencia del texto logran alcanzar una proyección social tanto en lo interno como externo de los sujetos. 


\section{Los poemas y su grito}

\section{1. "Los heraldos negros", versión primera}

Hay golpes en la vida tan fuertes... Yo no sé!

Golpes como del odio de Dios; como si ante ellos

la resaca de todo lo sufrido

se empozara en el alma... Yo no sé!

Son pocos; pero son... Abren zanjas oscuras

en el rostro más fiero y en el lomo más fuerte.

Serán tal vez los potros de bárbaros Atilas,

o los heraldos negros que nos manda la Muerte.

Son las caídas hondas de los Cristos del alma, de alguna fe adorable que traiciona el Destino.

Son esos rudos golpes las explosiones súbitas de alguna almohada de oro que funde un sol maligno.

Y el hombre... Pobre... pobre! Vuelve los ojos como cuando por sobre el hombro nos llama una palmada; vuelve los ojos locos, y todo lo vivido

se empoza, como un charco de culpa en la mirada...

Hay golpes en la vida tan fuertes!... Yo no sé!

\section{2. "Los heraldos negros", versión oficial}

Hay golpes en la vida, tan fuertes... Yo no sé!

Golpes como del odio de Dios; como si ante ellos, la resaca de todo lo sufrido se empozara en el alma... Yo no sé!

Son pocos; pero son... Abren zanjas oscuras

en el rostro más fiero y en el lomo más fuerte.

Serán talvez los potros de bárbaros atilas;

o los heraldos negros que nos manda la Muerte.

Son las caídas hondas de los Cristos del alma, de alguna fe adorable que el Destino blasfema.

Esos golpes sangrientos son las crepitaciones

de algún pan que en la puerta del horno se nos quema.

Y el hombre... Pobre... pobre! Vuelve los ojos, como cuando por sobre el hombro nos llama una palmada; vuelve los ojos locos, y todo lo vivido

se empoza, como charco de culpa, en la mirada.

Hay golpes en la vida, tan fuertes... Yo no sé! 


\section{3. $\quad$ El grito, de Edvard Munch (1893)}

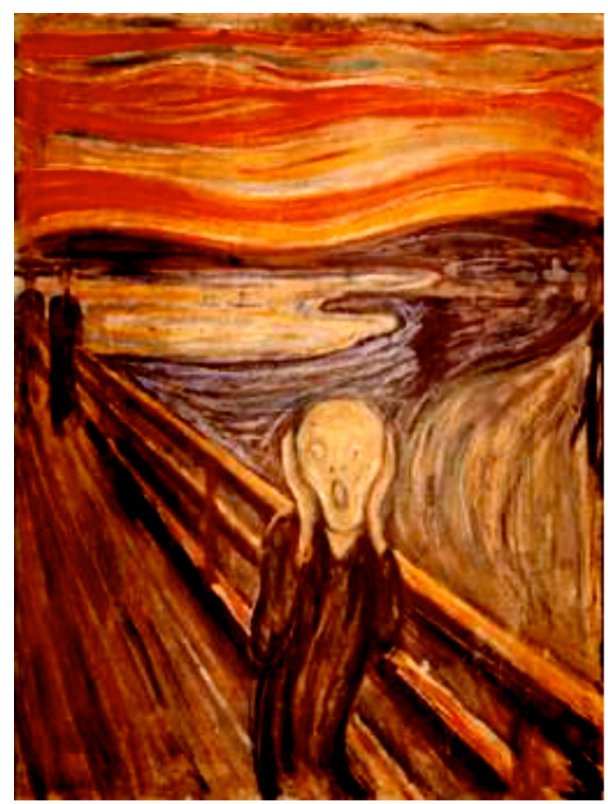

\section{Desde los golpes de Dios hasta el charco en la mirada}

Se procederá a analizar cada uno de los gramas intratextuales en ambas versiones por separado. Se establecerán comparaciones entre sí en la medida de lo posible, con tal de observar el cambio de significados sufridos desde una hasta otra estancia lírica. Se analizarán los gramas o símbolos de cada una de las versiones que permitan implantar posibles conexiones intertextuales con el texto de Munch.

\subsection{Relaciones intratextuales}

\subsubsection{Gramas fonéticos}

\subsubsection{1. "Los heraldos negros", versión oficial}

Desde la noción de los gramas fonéticos, se analizan las aliteraciones convocadas y las similitudes fonéticas y fonológicas de las unidades o palabras que conforman cada uno de los versos, de acuerdo con los rasgos descriptivos de la RAE (2011). En cada caso, se enfatizan los acentos del verso, pues, en la función poética de un poema, el ritmo determina cuáles son los fonemas principales. En algunos versos, coinciden los fonemas destacados con las sílabas acentuadas.

En el primer verso, con el fin de acentuar el símbolo de los 'golpes' y de su inevitable carácter dramático, se privilegian los sonidos oclusivos tanto sordos: /p/,/k/,/t/, como sonoros: /b/, /g/, /d/; así mismo, la fricativa /f/ con el objetivo de brindarle ese aspecto fluido, frecuente, insospechado, de los 'golpes', capaces de alcanzar a cualquier ser humano, en cualquier circunstancia y espacio. Aspecto que concluye bajo la acentuación vocálica de sílabas abiertas 
(CV), en donde se libera o enfatiza el desconocimiento causal de los 'golpes'; desconocimiento de los resultados de esos 'golpes' existenciales, convocados inicialmente por la escritura:

Hay golpes en la vịida, tan fuertes... Yo no no sé!

En el segundo verso, sucede casi homólogamente el fenómeno del primero, en tanto que se privilegian aún las oclusivas sordas (ahora también la $/ \mathrm{k} /$ ) y sonoras, puesto que se continúa hablando de los 'golpes'. Sin embargo, se presenta una antesala fonética para lo que será la causa principal del dolor humano: 'Dios'; pues, a partir de "[...] del odio de [...]”, se enfatiza el fonema /d/ que desembocará en el /d/ definitiva del dolor. Dicho fonema es apoyado por el cuarto acento del verso:

Golpes como del odio de Dios; como si ante ellos

Desde el tercer verso hasta el cuarto, la escritura enfatiza la aliteración de la /o/ y, más fuertemente, de la /a/, con la cual se va sobrecargando el dramatismo acústico sobre 'alma', símbolo contenedor de esos 'golpes'. El 'alma' será liberada como los 'golpes' al final del verso por medio de una acentuación vocálica abierta:

la resạca de tọdo lo sufrido

se empozara en el a almạ... Yọ no sée!

Durante todo el primer verso de la segunda estrofa, se muestra la aliteración de la /s/. Su carácter fricativo, en la frase cortada, junto a otras oclusivas sordas, acentúa esa incertidumbre ante la instancia del sufrimiento que sorprende repentinamente y, en definitiva, deja marca. Ese avance y retroceso entre fricativas alveolares $(/ \mathrm{s} /, / \mathrm{z} /)$ y velares $(/ \mathrm{j} /, / \mathrm{c} /)$ acentúan ese vacío zigzagueante propio de las "zanjas oscuras" en el ser:

Son pocos ; pero son... Abren zanjas oscuras

En el siguiente verso, ocurre una repetición de vibrante-labial-fricativa, que convoca respectivamente los símbolos físicos -espejos del dolor vivido-, dramatismo y persistencia incombatible de lo trágico en torno del ser humano:

en el rostro más fiero y en el lomo más fuerte

Aliteración de /s/, oclusivas sordas (/t/,/p/) y sonoras (/b/,/v/), además de vibrantes simples $(/ \mathrm{r} /, / 1 /)$; todas juntas en el tercer verso con tal de encaminarnos cadentemente hacia la metáfora síntesis del poema. Se introduce, así mismo, un símbolo clave: los 'atilas'. En el cuarto verso, parece privilegiarse las nasales, alveolares y labiales, respecto de su sonoridad y la ambientalidad generada frente a la posible significación absoluta de esos 'golpes'; o sea, la 'Muerte':

Serán talvez lo los potros de bárbarasos atililas;

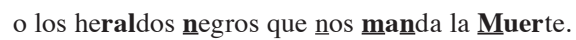

Sobre el primer verso de la tercer estrofa, también se privilegia la aliteración de la /s/, creando casi un torbellino, una atmósfera circulante y envolvente; mientras que en el verso siguiente, las alveolares, bilabiales y labiodentales. Se logra así, hasta el momento, la mayor combinación de sonidos en el área frontal de la cavidad bucal, reteniéndose una gran acentuación con la cual se resaltan al menos tres de los nuevos símbolos clave: 'fe', 'Destino' y 'blasfema':

Son las caídas hondas de los $\mathbf{C r i s} \underline{\text { tos }}$ del alma, de alguna fe adorable que el $\underline{\text { Destino }} \underline{\underline{\text { blasfema}}}$. 
En relación con los dos versos siguientes, undécimo y duodécimo del poema, en el primero, se reitera el aspecto envolvente de la aliteración de la /s/ junto al carácter imponente de las oclusivas, y no es de extrañar que ocurra cuando se retoman los 'golpes' explícitamente, ahora bajo una sinestesia auditiva, como puede ser la comparación con las 'crepitaciones', dentro de una imagen plásticamente lograda:

Eśsos golpes $\underline{\text { sangrientos }} \underline{\text { son }}$ las $\underline{\text { crepitaciones }}$

de algún pan que en la puerta del horno se nos quema.

Respecto a la última estrofa, en el primer verso, se presentan dos aliteraciones: una consonántica (/b/) y otra vocálica (/o/). Aquella da la sensación de esa atadura que pretende inútilmente ceder, y se ve acentuada por la vocal posterior /o/, la cual se prepara para dar cabida a un caos: a la segunda combinación de sonidos más representativos del poema:

Y el hombre... Pobre... pobre! Vuelve los ojos, como

Luego de esta retención inclusive de la respiración por la coma en torno a la /o/, se liberan ejemplares fonéticos de los que, hasta aquí, se han descrito no solo desde el punto de vista fonológico, sino también desde esa lectura transgresiva y permitida de los fonemas: la cadente ambientalidad de las oclusivas, al lado de las vibrantes simples y la aliteración envolvente de la /s/ que, junto a las nasales, conlleva considerar la presencia de un elemento externo, cercano, amenazante; ese elemento cautivante por un momento, en este caso, esa 'palmada'. Se revela también un nuevo sonido palatal en 'llama': esa llamada inevitable de estos 'golpes' casi de la misma forma íntima como una persona invitaría a otra, batiéndole suavemente el hombro, en señal de comprensión, afecto o lástima. En el poema, los 'golpes' le tienen lástima al 'hombre', pues su rumbo se dirige hacia la 'Muerte':

cuando por sobre el hombro no $\underline{\text { cos }} \underline{\text { llama }}$ una palmada

Pero de inmediato se vuelve al caos existencial: la atadura torbellina de la $/ \mathrm{b} /$ labiodental en conjunción con la /o/ rotunda, firme, frenética y caótica. Solo el sentido de la inutilidad del ser humano y su desesperación sin salida ante lo marginal de su existencia. Marginalidad, muchas veces, despierta por causa de la incapacidad de afrontar las más duras situaciones y retos cotidianos. Las mayores tragedias son cotidianas:

vuelve lós ojọs loccos, y tọdo lo vivivido

¿Y qué es "lo vivido", sino lo que "se empoza" en el recuerdo, en la dicha, en la esperanza; en lo que se escapa de las manos? ¿En las lágrimas? ¿Las derrotas acaso? Oclusivas cadentes conducen al lector hasta ese charco vocálico de la /a/, arrastrante proceso de /ch/ palatal, liberado por otra nasal que ofrece otro elemento, propio del dolor o su reflejo en el 'alma', pero distante en cuanto a solución: la 'mirada'. Véase:

se empoza, como charço de culpa, en la mirada

Vuelve el ciclo, así, fonética y semánticamente. Luego de torbellinos sonoros y cláusulas envolventes, el proceso no acaba. Se enuncia y evoca un continuum del dolor humano, pues, mientras se es humano, el dolor es inherente. Y no se sabe... Solo se espera... Solo se aguarda a sufrir de nuevo:

Hay golpes en la viida, tan fuertes... Yọ no sé ! 


\subsubsection{2. "Los heraldos negros", versión primera}

En la comparación de ambas versiones, los cambios más notorios relativos al orden de los gramas fonéticos ocurren tan solo en los dos últimos versos de la tercera estrofa de la versión primera.

En el primer verso de este par, se rescata el efecto envolvente de la aliteración de la sibilante /s/, más la presencia de algunas oclusivas. Se rescata en estos versos la imagen de los 'golpes'; se pretende crear una atmósfera cautivante con la metáfora:

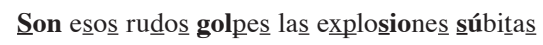

A partir de vocales como la /a/ y la /o/, se va creando a continuación una cadencia similar a la experimentada ante sonidos oclusivos, con tal de representar la sincronía de los 'golpes', uno a uno:

dẹ algunna a almohạda de o oro que fünde un sol mạligno

Sin embargo, comparando estos dos versos entre las versiones, se observa que ambos enunciados corresponden a imágenes secundarias dentro de las metáforas con mayor fuerza en el texto. En la versión oficial, la imagen, con un alto referente fenomenológico, resulta más simbólica y sensorial que esta imagen de la versión primera, la cual resulta un poco amanerada inclusive en su ritmo y plasticidad. Si se está escribiendo sobre los 'golpes': ¿Qué cautiva más: una imagen que remita a la sensorialidad crepitante de un cuerpo ante el fuego, semejante a un alma humana ante los 'golpes'; o un estallido de "almohada de oro", que ya por sí misma la almohada resulta sutil y delicada, poco dramática en relación con los 'golpes'? La imagen de la versión oficial, por consiguiente, posee un estilo más novedoso y atrevido en comparación con la de la versión primera, la cual trilla la estética modernista (Melis 1988; Yurkievich 1988) o postmodernista de algunos textos de Vallejo (Monguió 1954; Oviedo 1988; Mazzotti 1999; Faúndez 2009).

Sin embargo, los rasgos fonéticos empleados en ambas imágenes son similares. Cumplen una función similar, aunque difieran en estilo e intensidad: ambas utilizan en el primer verso la aliteración envolvente de la /s/ y durante el siguiente se pretende una cadencia representativa de los 'golpes', ya sea por oclusivas como en la versión oficial, ya sea por vocales abiertas en la versión primera.

\subsubsection{Gramas sémicos}

\subsubsection{1. "Los heraldos negros", ambas versiones}

En este nivel, se analizan aquellos semas o símbolos que de manera perifrástica envuelven a lo largo de todo el texto las pistas que guían al lector hacia un significado principal del poema como tal.

En primera instancia, los 'golpes' remiten a un lexema y sema, alrededor de los cuales el núcleo primordial de dicho texto se podría reducir. Por eso, cada poema configura enunciaciones sobre las causas u orígenes de estos 'golpes', consecuencias tanto físicas y existenciales en el ser humano; así como un despliegue variado de metáforas.

Los 'golpes' aparecen desde el primer verso en medio de una oración enunciativa inconclusa, con lo cual podría leerse el hecho de que se desconocen las causas de tales 'golpes'. Dicha lectura se ve reforzada por la cláusula inmediata: "Yo no sé!". Sin embargo, 
la pista central de la causa será aclarada en el segundo verso, con un peso singular, la cual tenderá a justificar las metáforas u otros semas que circunscriben el sema-lexema principal. Indudablemente, el "odio de Dios" es la causa que, por sí misma, eleva el dramatismo de esos 'golpes', desde un referente contingente y cotidiano en el ser, hasta uno mayor de crisis, como el religioso-filosófico, casi reflexivo y, por lo tanto, existencial. 'Dios' no es un ser de amor en este texto, sino proveedor de 'odio'; actúa y dicta arbitraria y rencorosamente contra el sujeto lírico y el ser humano en general, según aquel. Como afirma Martínez: "El sintagma odio de Dios remite, con toda seguridad, a la negación del Dios -que es «amor»- de Jesucristo y a la aceptación del Dios justiciero del AT que rechaza a quien le odia" (1988: 682).

Obsérvese, pues, el primer verso de la versión primera y la oficial, respectivamente:

Hay golpes en la vida tan fuertes... Yo no sé!

Hay golpes en la vida, tan fuertes... Yo no sé!

Se detectan cinco símbolos o metáforas simbólicas, más que cinco núcleos sustantivos aislados, circunscribiendo, enfatizando y reiterando de manera lúdica aquel sema-lexema central. Ellos se encuentran tanto en la segunda como tercer estrofa de ambas versiones.

El primero: "potros de bárbaros atilas'. Bien se mencionó que el sema "odio de Dios" justifica estas manifestaciones perifrásticas de los 'golpes' en la primera metáfora. En la segunda, al enunciarse los 'atilas', se remite fácilmente a la figura de Atila, quien fue un despótico caudillo de los hunos, tribu bárbara asiática, invasora de la parte occidental de Asia. Atila es conocido como: “el azote de Dios". Se enfatiza, pues, en la metáfora, un elemento indicial, casi sinecdótico de la tribu por sí misma ('potros'), acentuado por un adjetivo calificativo altamente dramático ('bárbaros'), para concluir no por la mostración en singular de la figura emblemática, sino en plural ('atilas'), con tal de generar un mayor carácter agónico y aniquilador, pero atenuado, pues se pierde la mayúscula del nombre propio. Considérese, de la versión primera y oficial, respectivamente:

Serán tal vez los potros de bárbaros Atilas

Serán talvez los potros de bárbaros atilas

El segundo: 'heraldos negros'. Desde la tradición clásica, los heraldos representan a aquellos mensajeros quienes anuncian sucesos o acontecimientos por suceder. Dichos personajes se encuentran comúnmente en la mayoría de tragedias griegas, con lo que se presuponen características caóticas en torno al arquetipo del 'heraldo'. Esta configuración aparece reforzada e intensificada por el adjetivo calificativo 'negros', con lo cual no solo se opaca plásticamente el arquetipo, sino que también se carga de connotaciones, apuntando de manera absoluta hacia el sema de los 'golpes'. Al respecto, léase en ambas versiones.

o los heraldos negros que nos manda la Muerte

El tercero: 'caídas'. La recurrencia a este sema podría explicarse por el hecho de que todo ser humano 'cae' inevitablemente ante la presencia de 'golpes' en su vida. Las 'caídas', al igual que los 'golpes', poseen una connotación decadente, degenerativa, desarticulante. Por tanto, la asociación de ambos semas en el que este circunscribe a aquel resulta totalmente válida desde una relación, por analogía, desestructurante del ser. Martínez afirma:

\footnotetext{
El lexema caída ha tenido desde siempre en la doctrina religiosa el sentido negativo de «pecado» [...] Pero la expresividad poética se intensifica porque caída es una referencia tradicional a Cristo camino del Calvario y cayendo bajo el peso de la Cruz [...] Las caídas de Cristo han sido siempre puestas en relación doctrinal y moral con las «caídas personales», es decir, con los pecados. Desde esta perspectiva, adquiere un relieve más acusado la referencia Cristos del alma (1988: 683)
} 
El cuarto: 'Cristos'. En este caso, se pluraliza una de las figuras más destacables en la cultura occidental: Cristo; sin embargo, su pluralización no interfiere con el significado de esa flagelación, de ese sufrimiento que bien puede tomar como víctima a cualquier humano, pues en el fondo todos los seres humanos son 'Cristos', todos son "hijos de Dios". Nótese, además, según la tradición católica, que Cristo es quien se entrega al sufrimiento, obtiene la 'muerte', pero aún así logra trascender en su espíritu a través de la resurrección. Por tanto, los 'golpes' se encuentran asociados a un plano de existencia física. Ellos, si bien pueden atentar contra el ser en un nivel espiritual, pierden todo efecto aniquilante en el plano superior de la consciencia mística y metafísica del cosmos. Cristo llegó hasta donde debía llegar. Cumplió con los mandatos del Padre. Entonces, ¿son los 'golpes' los ‘heraldos' de que la estadía y acciones del ser humano van llegando a su final en esta tierra y en esta vida? Léase, para ambas versiones:

Son las caídas hondas de los Cristos del alma

Hasta aquí, todos los semas o metáforas simbólicas circunscritos a 'golpes' resultan idénticos para las dos versiones. El único cambio encontrado es el de 'crepitaciones' por 'explosiones'. El primer sema se encuentra en la versión oficial, en la cual los 'golpes' se asocian a los ruidos producidos por la leña al arder. Se relacionaría, pues, la leña con los huesos del ser humano: huesos que se doblegan, sufren fisuras, se quiebran ante el impacto e ímpetu de los 'golpes' en el ser. Cada 'golpe' provoca una 'crepitación', ruido que bien puede ser sentido a lo largo del cuerpo y en la memoria del ser humano cuando es víctima del dolor. Cada 'golpe' es un 'pan', un alimento que mantiene a los seres humanos vivos y los lleva a la 'Muerte' o a la angustia existencial. Las 'explosiones' brindan una connotación similar a las 'crepitaciones', en tanto que se refieren a la destrucción de esa "almohada de oro", la cual puede sugerir el pecho, el plexo solar del ser humano, ante el dolor inflicto y significativo en la vida. Al respecto, considérese, de la versión primera y la oficial, respectivamente:

Son esos rudos golpes las explosiones súbitas

de alguna almohada de oro que funde un sol maligno.

Esos golpes sangrientos son las crepitaciones

de algún pan que en la puerta del horno se nos quema.

En definitiva, los cinco semas o metáforas refuerzan el sema-lexema principal y conducen la tensión expresiva a un solo eje, un sema culminante y definitivo dentro del poema y sobre cualquier lectura sugerida: la 'Muerte'. Si bien una causa fuera el "odio de Dios", la consecuencia dramática, poco evasiva y rotunda, resultaría el término de la vida humana.

Aunque la 'Muerte' puede ser la consecuencia absoluta de esta presencia tormentosa para el sujeto lírico, puede encontrarse también consecuencias en el nivel espiritual, las cuales a su vez pueden dividirse en un sentido místico o físico.

Los 'golpes' y todos sus efectos dramáticos encuentran cabida en el 'alma' humana. En este punto, debe considerarse la relación psique-cuerpo. La psique, altamente relacionada con las emociones, la abstracción y la trascendencia espiritual se ve tentada a ignorar, culpabilizar y alejarse de toda aquella 'fe' en la cual se creía anteriormente. Es decir, el ser humano, ante la posibilidad de que la causa de sus 'golpes' sea 'Dios', renuncia a todo ideal y dogma religioso que le aseguraba un rumbo amparador, seguro y prometedor. Es acá cuando, en los momentos de crisis, el 'Destino' blasfema las creencias y verdades que mantienen a cada ser, por una parte, como un sujeto cultural y perteneciente a un espacio y contexto propio, tanto en la otredad (lo social) como en la mismidad (subjetividad). 
Así, pues, se presenta una pugna entre un determinismo, con que el 'Destino' prescribe al sujeto y en donde se incluyen estos 'golpes' inexorables, y la 'fe' de todo ser ante la opción volitiva e individual de acción y decisión, de libre albedrío, la cual es cuestionada y rechazada por los embates del dolor humano.

Si se destaca en este punto el sema 'Cristos', trayendo a colación el detalle de que es el Cristo bíblico quien se entrega al sufrimiento pues ya había realizado el proyecto del Padre, entonces, parece existir un determinismo en torno a los 'golpes' que el ser humano sufre. Esos 'golpes' que el ser humano tiende a atenuar, cuando proceden de acciones desmedidas y erradas de la voluntad y transporta a aquel a un nivel de culpa absoluta.

En el nivel físico, las marcas del dolor resultan aún más claras. En este sentido, se evidencian 'zanjas' en dos ángulos vitales para el ser: en el 'rostro', pues es este símbolo de la fortaleza e ímpetu para enfrentarse al mundo. Y no importa: débil o 'fiero', siempre será alcanzado por el dolor. Además, el 'lomo' también representa este emprendimiento y trabajo por aceptar y resolver los trabajos cotidianos; así como la capacidad de cargar con los más grandes pesares experimentados. Y no importa: débil o 'fuerte', siempre será alcanzado. Nótese, entretanto, que 'rostro' y 'lomo' demarcan, metonímicamente, el envés y anverso de todo sujeto, por lo cual se supone que los 'golpes' se avienen o invaden desde cualquier sitio, contexto o circunstancia contra cualquier ser prevenido o no. No hay escapatoria: el ser humano es víctima desde cualquier ángulo.

También en el nivel físico, se encuentra otro sema en la última estrofa: los 'ojos'. Popularmente, se ha dicho que "los ojos son las ventanas del alma". Y si se dijo antes que los 'golpes' encuentran cabida en el 'alma', es posible que los 'ojos' contengan ese "charco de culpa”, esa impotencia, esa desarticulación no solo física sino moral, ética, espiritual del ser ante el dolor que le acomete inevitablemente.

En síntesis, se podría concretar la presencia y relación de todos estos semas, en la producción y orientación del significado manifiesto en el texto, de la siguiente manera:

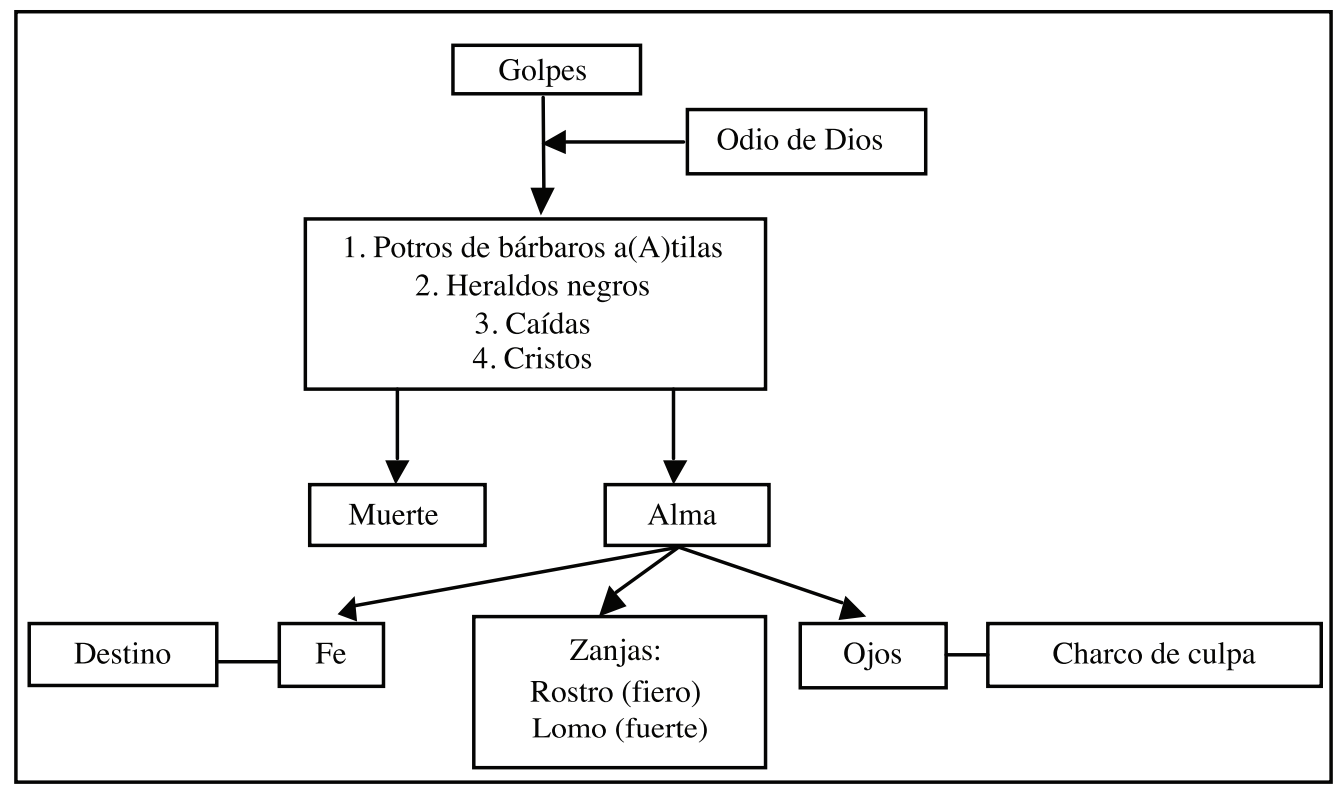

Cuadro 1. Relación de los semas presentes en ambas versiones de "Los heraldos negros" 


\subsubsection{Gramas sintagmáticos}

\subsubsection{1. "Los heraldos negros", versión oficial}

Para este nivel se pretende analizar la secuencia de esa materia nebulosa (Sarduy 1977) que sostiene un proceso dentro del texto, con lo que resulta pertinente identificar y describir los elementos morfosintácticos (RAE 2010), su distribución, contradicciones y enlaces para la configuración de significados.

Durante la primera estrofa, el significado parte de una oración impersonal gramatical en que se alberga el sema-lexema principal ('golpes'). No obstante, dicha cláusula se encuentra reforzada hacia el final por una frase explicativa ("tan fuertes"), por medio de una pausa respiratoria representada ortográficamente por una coma. Esta frase intensifica la carga dramática de estos 'golpes'. Carga, que a su vez, reintensifícase con una pausa mayor establecida por los puntos suspensivos, los cuales otorgan un efecto de incertidumbre alrededor de aquel sema-lexema planteado desde el principio del mismo verso. Tales puntos suspensivos indican una reticencia ${ }^{1}$ (Fernández 1972), cuyo objetivo es aumentar intencionalmente la sugestión patética sobre los efectos de los 'golpes' de la vida.

Se concluye el primer verso con una oración psicológica enunciativa negativa ("Yo no sé!’), en la cual se refuerza el carácter de lo incierto sugerido por los puntos suspensivos. Nótese que dicha cláusula concluye con un signo de exclamación que acentúa el desconocimiento del sujeto lírico ante la causa, procedencia, lógica, motivo, razones, circunstancias, entre otras, de estos 'golpes'. En fin, en el sema principal, se muestra y se desconoce a la vez, en un juego de presencia-ausencia.

Los tres versos siguientes constituyen entre sí un solo sintagma nominal, cuya función radica en aclarar y fortificar el sema-lexema inicial. Para ello, se reitera al principio del verso como pauta central y circunscribe, así, un ciclo de dos comparaciones. En la primera, se sospecha el motivo causal de estos 'golpes'; mientras que en la segunda, incorporándose una pausa respiratoria que genera ambientalidad o preparación para la imagen siguiente, únicamente interesa proponer un acto consecuente de estos en el ser humano. Se vale el lenguaje de una subordinación circunstancial que, evidentemente, concluye con la utilización de puntos suspensivos y de la misma oración psicológica anterior, con tal de demostrar que ni siquiera la lengua es capaz de definir el efecto, explicación o manifestaciones del dolor humano. La lengua le es insuficiente al lenguaje. El dolor es un excedente de significación. Léase, por tanto:

\footnotetext{
Hay golpes en la vida, tan fuertes... Yo no sé!

Golpes como del odio de Dios; como si ante ellos,

la resaca de todo lo sufrido

se empozara en el alma... Yo no sé!
}

En relación con la segunda estrofa, esta inicia con una oración copulativa cuyo sujeto táctico corresponde a los 'golpes' y, cuyo complemento predicativo, es el adverbio 'pocos', con lo cual se destaca un nuevo valor alrededor del sema: el dramatismo e ímpetu de un solo sufrimiento significativo antes que la numerosa cantidad de estos en la vida. Este valor se acentúa con la conjunción adversativa 'pero', acompañada por el verbo copulativo 'son', asociado a la existencia y, por tanto, a la presencia física y determinante del dolor humano en su condición vital, desconocida a la vez. Nótese como afirmador de esto último los puntos suspensivos de nuevo. 
Pero el verso no acaba. Continúa con una oración transitiva en la que el objeto directo enuncia una consecuencia física del dolor ('zanjas'). Dicha consecuencia se encuentra limitada por dos complementos circunstanciales de lugar, pues resulta pertinente enfatizar este efecto consecuente en el ser, pero no en cualquier parte de su cuerpo, sino en partes simbólicas de él: "en el rostro" y "en el lomo".

Los dos últimos versos conforman una oración psicológica dubitativa determinada por el modo subjuntivo del verbo ('Serán') y por el adverbio de duda ('talvez'). El sujeto tácito de la oración (los golpes) es asociado a dos nuevos complementos predicativos; en estos casos, los núcleos de tales atributos corresponden a sustantivos. En el primero, el núcleo resulta el sema 'potros', cargado semánticamente por el complemento adnominal: "de bárbaros atilas". En el segundo, el núcleo resulta 'heraldos', sema intensificado en sus virtualidades semánticas y, por tanto, en los niveles de sugerencia por el adjetivo calificativo 'negros' y una oración subordinada adjetiva, la cual aporta uno de los posibles actos consecuentes del dolor: la 'Muerte'. Obsérvese:

\footnotetext{
Son pocos; pero son... Abren zanjas oscuras

en el rostro más fiero y en el lomo más fuerte.

Serán talvez los potros de bárbaros atilas;

o los heraldos negros que nos manda la Muerte.
}

Con respecto a la tercera estrofa, se repite el modelo sintáctico-morfológico. Inicia con una oración copulativa, cuyo sujeto permanece tácito, y cuyo complemento predicativo posee como núcleo un participio en función sustantiva ('caídas'), sema asociado con la desestructuración del ser ante el dolor. No obstante, este se ve reforzado por un adjetivo calificativo ('hondas') y un complemento adnominal que incorpora el sema 'Cristos', con toda su carga religiosa, limitado por otro complemento adnominal de locación ("del alma”), el cual con la pausa respiratoria de la coma permite al lector detenerse en el espacio interior del sujeto lírico. 'Del alma' se encuentra relacionado con otro complemento adnominal, que incorpora el sema 'fe'. Este último, por medio de una oración subordinada de relativo, sostiene su contraparte cuestionable: 'Destino'.

Los dos últimos versos no escapan de esos componentes morfosintácticos: complementos adnominales y oraciones subordinadas de relativo juntos conforman el complemento predicativo de la oración copulativa. La estructura base es: Oración copulativa ([Sujeto nominal] + verbo copulativo + complemento predicativo (complemento adnominal + oración subordinada de relativo)). El sujeto nominal corresponde al mismo que de manera tácita venía utilizándose ("Esos golpes sangrientos"), pero calificado en esta oportunidad por el adjetivo 'sangrientos', el cual agrega nuevas virtualidades al sema-lexema principal. El núcleo sustantivo del complemento predicativo corresponde al sema 'crepitaciones', el cual dirige la lectura hacia el deterioro interno del ser. El complemento adnominal que depende de dicho sema incorpora el elemento 'pan', elemento anteriormente relacionado con el alimento-veneno que son los 'golpes'. Es decir, el 'pan' de vida y muerte, ubicado por una oración subordinada de relativo en la "puerta del horno", que bien podría leerse como un giro perifrástico de 'alma':

Son las caídas hondas de los Cristos del alma,

de alguna fe adorable que el Destino blasfema. 
Esos golpes sangrientos son las crepitaciones

de algún pan que en la puerta del horno se nos quema.

En la cuarta y última estrofa, se inicia con una conjunción copulativa ('y'), con la cual se ligan las situaciones temáticas mencionadas anteriormente con las nuevas. Esta conjunción, así mismo, introduce un sintagma nominal incompleto intencionalmente. Aparece su núcleo sustantivo ('hombre'), más un solo adjetivo calificativo ('pobre') reiterado, con el fin de crear este sentimiento de desdicha e infortunio, recurriendo entre tanto a los puntos suspensivos tan usados antes también. Se continúa con una oración transitiva en la que el objeto directo corresponde a los 'ojos', sema que simboliza el contenedor o nexo del sufrimiento entre el espacio interior y el espacio exterior del ser humano. Se establece una pausa, con tal de darle más fuerza a la oración subordinada circunstancial que sugiere una fuga del ser ante el dolor o una 'llamada' del dolor al ser en el segundo verso.

Los dos últimos versos reanudan el modelo de la oración transitiva. El sujeto tácito en ambos casos corresponde al 'hombre'. El objeto directo se ve reforzado en sus virtualidades por el adjetivo calificativo ('loco'). Por coordinación copulativa se une esta cláusula a la última, la cual posee un sujeto nominal cuyo núcleo sustantivo es "lo vivido"; sujeto que, de manera reflexiva, toma cabida significativa "en la mirada". Este último complemento circunstancial locativo se relaciona con el objeto directo de la oración transitiva inmediatamente anterior a esta, con lo que el sema 'ojos' se asocia dramáticamente con la frase explicativa: "charco de culpa" aparece, a modo de equivalencia semántica. Dicha frase, al encontrarse entre pausas respiratorias (entre comas), genera todo un detenimiento en la corriente de conciencia del poema, arrojando al lector hacia esa inevitabilidad y misterio del dolor. Considérese, así:

\footnotetext{
Y el hombre... Pobre... pobre! Vuelve los ojos, como

cuando por sobre el hombro nos llama una palmada;

vuelve los ojos locos, y todo lo vivido

se empoza, como charco de culpa, en la mirada.
}

Si se habla de su inevitabilidad, incertidumbre y misterio, el dolor parece acabar con la vida del ser humano. Sin embargo, el sujeto lírico expresa el hecho de que no ha terminado una ráfaga de crisis cuando ya el ser humano experimenta otra. Parece que, por más apaciguamiento de las circunstancias contingentes, el sujeto lírico experimenta nuevas pruebas existenciales. Esto es sugerido por la reiteración absoluta de las cláusulas impersonal y psicológica introductoras del poema, y ahora lo concluyen sin terminarlo, pues estructuran una acción cíclica, como casi todos los sucesos dramáticos de la vida obedecieran tal ciclicidad:

\footnotetext{
Hay golpes en la vida, tan fuertes... Yo no sé!

$[\ldots]$

Hay golpes en la vida, tan fuertes... Yo no sé!
}

\subsubsection{2. "Los heraldos negros", versión primera}

Es en el nivel sintagmático donde aparecen mayores diferencias entre ambas versiones del poema. En la primigenia versión, no se experimenta una frase explicativa que intensifique 
el dramatismo inicial en torno al sema-lexema principal del poema durante el primer verso. Al eliminar la pausa respiratoria posterior a 'vida', el enunciado corresponde a una sola idea, sin acentuaciones enfáticas más que la presencia de los puntos suspensivos, ante los cuales el verso ha agotado ya un ritmo poco cadente.

Al final del segundo verso, justo cuando comienza la segunda comparación hecha dentro del largo grupo nominal constituido por los tres versos finales de esa estrofa, no se encuentra ninguna pausa respiratoria que detenga la corriente del lenguaje ni el encabalgamiento de toda la imagen. No se da una preparación de impacto, sino más bien un fluir natural de la imagen, casi independiente, por sí misma.

En el tercer verso de la segunda estrofa, en el complemento predicativo "los potros de bárbaros Atilas" de la oración copulativa se destaca un elemento que intensifica la simbolización. 'Atilas' aparece en mayúscula; recurso que se pierde en comparación con la versión oficial. Sin embargo, esta mayúscula les presta mayor personificación a los 'golpes' simbolizados por 'Atila'. No es ya un 'Atila' que actúa, amenaza, destruye o aniquila por sí solo; se trata de muchos 'Atilas', inclusive cuando se hable de un único 'golpe' pues, en una misma situación de crisis, múltiples aspectos condicionan o detonan el problema existente. Véase:

Serán tal vez los potros de bárbaros Atilas;

o los heraldos negros que nos manda la Muerte.

Respecto del segundo verso de la estrofa tercera, el hipérbaton se apodera de la oración subordinada adjetiva. Posterior al pronombre relativo 'que', el verbo antepónese al sujeto nominal ('Destino'). La posición de este después del verbo en la oración tiende a restringir (Fernández 1972) la fuerza en la corriente del lenguaje, pues parece un acto racional analítico, pensado, poco creíble desde el punto de vista coloquial del poema con el lector. La ubicación del sujeto antes del verbo en esta misma oración subordinada en la versión oficial enfatiza, al contrario, una intención meramente irónica en cuanto a la acción; ironía que, en esta versión, se pierde o disminuye.

La acción verbal atribuida al sujeto ('Destino') en la versión oficial corresponde a 'blasfema'; en esta versión, 'traiciona'. La traición sugiere siempre un acto deliberado, frío, realizado; mientras que la blasfemia, un acto realizable en un tiempo presente, poco deliberado, espontáneo, acorde con las inquietudes y las crisis experimentadas por el sujeto. Es por ello que, entre ambas posibilidades, en conjunción con el lugar del sujeto antes o después, del verbo, 'blasfema' corresponde a una acción aún más dramática y semantizada que 'traiciona'. Compárense los versos de la versión primera y la oficial, respectivamente:

\footnotetext{
Son las caídas hondas de los Cristos del alma,

de alguna fe adorable que traiciona el Destino.

Son las caídas hondas de los Cristos del alma,

de alguna fe adorable que el Destino blasfema.
}

Obsérvese que, en los versos tercero y cuarto de esa misma estrofa, la imagen poética inicia con el verbo copulativo tal y como se da anafóricamente en dos de las tres oraciones anteriores en el poema. Sin embargo, el sujeto que antes era manejado tácitamente ahora se incluye de manera nominal; su núcleo sustantivo es reforzado por el adjetivo calificativo 
('rudos'), el cual agrega un nuevo valor en los niveles de sugerencia. El complemento predicativo de la oración está constituido, así, por un núcleo sustantivo ('explosiones') más un adjetivo calificativo especificativo, un complemente adnominal que incorpora el elemento 'almohada'; este último admite el símbolo 'oro' mediante otro complemento adnominal, aspecto que permite la subordinación de una cláusula de relativo como justificación del sema 'explosiones'. Considérese:

Son esos rudos golpes las explosiones súbitas

de alguna almohada de oro que funde un sol maligno.

Al final del primer verso de la cuarta estrofa, la pausa respiratoria después del objeto directo ('ojos') no se da. Ocurre lo mismo que en el segundo verso de la primera estrofa y ambos comparados con la versión oficial. La pausa respiratoria en ambos casos prepara, refrenando la corriente del lenguaje, y con mucha mayor intensidad, la imagen siguiente. Su elisión produce una sola imagen encabalgada entre los pares de versos sin ningún énfasis ni acentuación que altere el ritmo de la imagen hacia una mayor carga dramática. En el cuarto verso de esta última estrofa, se encuentran tres cambios.

La frase explicativa de la versión oficial ha desaparecido. Sin embargo, aún se conservan algunos elementos que pierden síntesis en la imagen. El sintagma "como un charco de culpa" sustituye a "como charco de culpa". La incorporación del indefinido 'un', aunque es asimilado por una sinalefa, altera el ritmo, disminuyendo la fluidez del verso.

Se halla la supresión de la coma posterior a 'culpa', con lo que se construye una imagen no retenida desde 'como' hasta 'mirada'. Y se incorpora un nuevo elemento, empleado a lo largo de ambas versiones: los puntos suspensivos, los cuales al término de esta imagen pretenden generar una última ambientalidad de misterio y desconocimiento ante el dolor. Con estos signos de puntuación, las sugerencias finales de la reticencia quedan abiertas.

$\mathrm{Y}$, aunque el verso final permanece casi idéntico al primero, con la intención de estructurar el ciclo inevitable del sufrimiento, se agrega un signo de exclamación posterior a 'fuertes', con lo que se advierte su presencia definitiva, pues se aclara una curva progresiva de entonación in crescendo hacia el final. Se intensifica, así, el anuncio rotundo de la existencia caótica de todo sujeto, inexplicablemente, ante los 'golpes'.

\subsection{Relaciones intertextuales}

Las relaciones intertextuales que se establecen entre dos o más textos dependen en gran medida de los vértices tendidos entre los gramas sémicos que conforman, desde el nivel intratextual, dichos textos. Las marcas reminiscentes comprenden aquellas marcas que en los estratos profundos de los textos involucrados se logran identificar (Sarduy 1977). No obstante, dichas marcas se encuentran circunscritas o tratadas de manera perifrástica en torno a uno o varios semas principales.

En ambas versiones de "Los heraldos negros", se ha aclarado que el sema-lexema principal corresponde a 'golpes'. Valiéndose de este y de otros semas o símbolos, así como de los elementos más destacados en el nivel sintagmático, se procederán a establecer relaciones intertextuales entre las versiones y el texto de Munch. Antes bien, resulta importante determinar los semas que componen la pintura citada. 


\subsubsection{Gramas sémicos}

\subsubsection{El grito}

Se analizarán tres estancias diferentes para el análisis: a) los colores, b) el escenario físico y la otredad; y c) el sujeto principal.

En cuanto a los colores, predominan el cromatismo cálido del rojo y el amarillo; en efecto, también se destacan colores intermedios como el anaranjado, amarillo verde y el púrpura rojo. El realce y sensación provocada por los colores intensifican una problemática proyectada desde el espacio interior del sujeto representado hasta el espacio exterior que lo rodea. Sugieren una actitud fluctuante y altamente ligada a las expresiones emotivas de la psique humana.

Pero no se trata de cualquier espacio físico. Corresponde al cielo; simbólicamente, este representa el deseo de trascender los límites humanos, un plano de consciencia superior a lo circunstancial; es decir, la pretensión de lo trascendental, místico, enigmático, sagrado, inaccesible y perenne frente a lo contingente del mundo caótico (Chevalier y Gheerbrant 1988).

Los colores fríos o tonalidades derivadas de estos como el café se presentan en aquellos elementos que bien se relacionan con la fijación meramente terrestre, la limitación contingente del ser humano más allá de su plano espiritual y su abstracción; es decir, el puente, las vestiduras de los sujetos representados y el borde de lo que pareciera una playa, escenario proyectado después del primer plano del puente.

Desde el discurso expresionista, el texto pretende destacar a partir de todos sus elementos, la crisis psicológica del ser. No cabe ninguna duda de que el contraste entre colores cálidos y fríos representa los mismos estados alternos en medio de una problemática existencial, estado de reposo, inquietud y angustia a la vez.

Desde el escenario convocado en el texto, se identifican, en tres planos, elementos distintos. En el plano superior del cuadro, el cielo representa lo abstracto y trascendental al ser. Sugiere a partir de estos colores cálidos que lo conforman una rauda angustia que precede o se encuentra ya determinada ante la existencia de cada ser.

En el plano intermedio, se ubican la playa, el puente y los dos sujetos. La playa connota ese límite entre el mundo marino y terrestre. Se podría considerar el agua como símbolo de la trascendencia, lo desconocido para el ser humano, o bien del espacio interno cambiante -como un mar- (Chevalier y Gheerbrant 1988); mientras que el mundo de lo terrestre se asocia con lo contingente y fenomenológico de las realidades que rodean al ser, en tanto sujeto social e histórico; es decir, la otredad, el sentimiento de pertenencia a un contexto tangible, ético, político, socioeconómico, entre otros.

El puente es siempre una opción, un camino construido a partir del raciocinio humano, un producto del ser en cuanto solución para un problema. Su dirección posibilita una lectura desde atrás hacia delante, se tiende desde el agua buscando tierra; o viceversa. Lo interesante sería que el mismo puente representa un artificio humano en busca de soluciones atravesando para ello planos o circunstancias cotidianas diferentes pero complementarias entres sí: desde el espacio interior hasta el espacio exterior, o viceversa.

El puente, además, es misterioso; pues, ante la posibilidad de establecer una lectura bidireccional desde la tierra y el agua, cabe, entonces, preguntarse: ¿cuál es el comienzo del puente y cuál, su término? ¿Inicia al fondo y concluye en el plano frontal del cuadro, o 
viceversa? ¿Dónde comienza el puente? Considérese que este comienza a partir de la dirección que el transeúnte traiga y como lo aborde. Todo es relativo. Por lo tanto, el puente no inicia ni termina, solo está. En todo caso, en este cuadro, el sujeto principal "anda corriendo, pero parece que dondequiera que vaya el lugar es el mismo. El hombre corre por las calles angustiadas y por las «secretas galerías de su alma» apesadumbrada" (Juliá 1988: 101).

Los dos sujetos representados hacia el fondo de la pintura sugieren que el ser humano no se encuentra solo, aún en los momentos de crisis. Aquellos son testigos del sufrimiento del sujeto principal. Su distanciamiento respecto del sujeto del primer plano, así como su falta de rostro definido, sugieren uno de los fenómenos más comunes en una sociedad marcada por el materialismo y la vivencia de consumo: la indiferencia, la cual conlleva la soledad, asociada también al dolor, la crisis y la predominancia de colores fríos en torno a los tres sujetos.

Evidentemente, el sujeto frontal del cuadro constituye el sema principal del texto: la desesperación ante el dolor humano ('el grito'). En él, se conjugan varios elementos y recursos estilísticos. Primero, la distorsión. Este recurso expresionista exagera e intensifica el sema del dolor y sus valores de sugerencia trágica tanto en el espacio físico-exterior como emotivointerior del sujeto principal. Su cuerpo se ve deformado en comparación con una simetría objetiva, con tal de connotar quizás los efectos dramáticos del dolor: "estas rayas curvas, además de crear un ambiente extraño, acentúan la intranquilidad y la pesadumbre. Las rayas moviéndose en el espacio, mientras las figuras parecen estar casi inmóviles, manifiestan plásticamente la actividad interior: el sufrimiento y el pavor" (Juliá 1988: 100).

$\mathrm{Su}$ cuerpo, exceptuando el rostro, se encuentra cubierto con un vestido café, lo cual lo hace parecer un viejo tronco de árbol, tierra infértil; sugiere, entre tanto, lo seco y destruido interiormente.

El rostro y las manos poseen un tono frío que sugiere la debilidad como acto consecuente del sufrimiento. La desesperación toma expresión a partir de la pronunciación gestual de la boca y de los ojos dilatados. La oscuridad y la luminosidad que escapan de los ojos acentúan lo hiriente del grito. Las manos son elevadas como en un acto de rendición con el último afán de sostener el rostro, afirmación dura de que el ser ha sido derrotado y opreso por circunstancias o hechos desconocidos e incontrolables a él mismo.

El sujeto ubicado sobre el puente (lo misterioso de la vida) ha hecho un alto para gritar. Ese alto es un instante de reflexión, derrota, subordinación, de muerte tal vez. Es un alto de un alguien que será alcanzado de repente por otros, de repente aterrorizado; de repente solo, de nuevo. En este cuadro, como en otros de Munch, el tiempo parece haberse detenido y el sujeto principal parece estar inmóvil o "moviéndose a un tempo más lento del acostumbrado" (Julián 1988: 99).

Todos los semas analizados desde las tres instancias (los colores, el escenario físico y la otredad, y el sujeto principal) encuentran un vértice en común: el rostro del ser, su grito, su impotencia.

\subsubsection{Elementos intertextuales y posibles relaciones}

Teniendo ya referencia sobre los semas y otros elementos del texto de Munch, se establecerán relaciones intertextuales con los semas y algunos gramas sintagmáticos de ambos poemas. Para ello, primero, obsérvese el siguiente cuadro, donde se muestran conexiones de sentido posibles: 


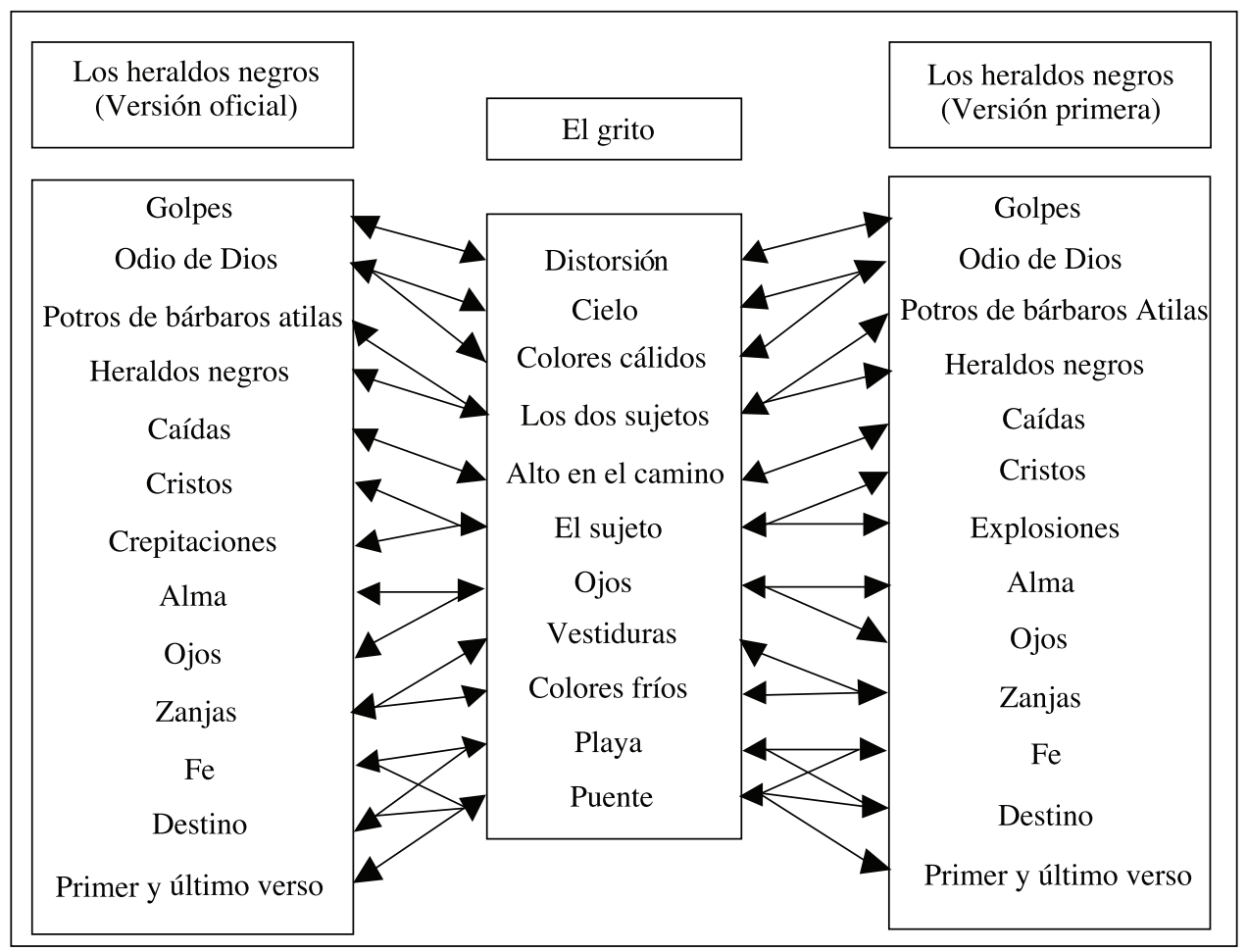

Cuadro 2. Relaciónes intertextuales de semas y gramas sintagmáticos de ambos poemas y El grito

Como sema-lexema principal en ambos poemas, los 'golpes' avasallan al ser en niveles emotivos, psicológicos y físicos; existenciales, en fin. La 'distorsión' planteada como recurso estilístico del expresionismo permite una lectura de presencia y consecuencia de estos 'golpes' vitales en el ser, los cuales vienen a reformular las estructuras o visiones de mundo que el sujeto principal del cuadro poseía, quizás, antes de la crisis experimentada. Estos 'golpes' afectan no solo la percepción del espacio exterior -reflejo del espacio interno-, sino que también deforma el físico del sujeto; esto se sugiere a partir de la curvatura del torso de manera cóncava, como simulando la huella de un puño, de un 'golpe', y ello causa dolor evidentemente.

Los colores cálidos y el cielo se encuentran intrínsecamente relacionados. El cielo representa lo más alto, casi prohibido y desconocido para el ser; la inaccesibilidad a un plano superior (Chevalier y Gheerbrant 1988). 'Dios' se ubicaría en este mismo plano. La simulación o sensaciones inspiradas por los raudos colores entrelazados sugieren de manera vívida ese 'odio' tan temido de 'Dios'. El cielo cubre todo el ámbito terrestre. Los sujetos representados del cuadro y los sujetos líricos de ambos poemas pertenecen a él. Por tanto, 'Dios' también está sobre ellos y es capaz de desatar su furia, quizás 'odio', contra los de abajo.

Sobre los dos sujetos hacia el fondo de la pintura, su postura sugiere un acercamiento inevitable, un acto casi de anunciación similar al de "los potros de bárbaros A(a)tilas" o "los heraldos negros". Sus vestiduras igualmente opacas connotan el dramatismo y misterio de la muerte. No se sabe quiénes son. No poseen 'rostro'. De todas formas, los 'golpes' llegan hasta los sujetos líricos y principal del cuadro sin saber si quiera su causa a veces, ni el tiempo cuando aparecen. 
El detenimiento del sujeto representado en uno de los puntos del puente remiten al alto que el dolor obliga hacer con tal de sobrellevar los actos consecuentes, o bien analizar las circunstancias y todo "lo vivido". En este sentido, el ser humano se detiene, sufre, grita, se cae, como Cristo: Sufre un derrumbamiento de su ser. Por ello, el sema 'caídas' se relaciona fuertemente con el alto hecho por el sujeto representado en su camino, en su vida.

Recuérdese que el sema 'Cristos' remitía a la figura homónima en singular. Cristo se entrega a los 'golpes' que le pertenecían predestinadamente, para luego ser redimido. Quizás con esa misma inquietud existencial de salvación, el ser humano se rinde ante el dolor, quizá teniendo 'fe' en esa tan dudosa 'fe' suya ahora.

El sujeto representado es quien sufre las "explosiones súbitas" del inexorable sufrimiento. Él es víctima; él es actante de su imaginaria voluntad; tan solo grita como símbolo de la desesperación, la incertidumbre, el riesgo, la nada. Las vestiduras del sujeto, debido a su color frío, sugieren el color de la tierra seca, de un tronco viejo y seco. Las 'crepitaciones' recuerdan el ruido de la madera ardiendo. ¿Por qué no pensar, entonces, que ante el dolor las mismas 'crepitaciones' del 'alma' y el cuerpo físico anuncian la destrucción del ser en toda su unidad existencial?

Uno de los semas claramente identificable en los tres textos es los 'ojos'. Ellos connotan el límite del mundo intrapersonal e interpersonal del sujeto. Asimismo, representan un "espejo del alma". La distorsión y la crisis dolorosa del 'alma' resultan reveladas por medio de este portal. Por tanto, la relación intrínseca y dependiente entre los semas 'ojos' y 'alma' resulta crucial en la generación del sentido dramático de los textos y de los niveles agónicoexistenciales del ser.

El color frío de las vestiduras del sujeto representado hace pensar al espectador en la tierra. Si todo el ser ante el dolor es herida, la relación establecida entre su naturaleza física en detrimento y las 'zanjas', las cuales son heridas en la tierra, es notable. En este sentido, todo ser humano es tierra y, por tanto, herida.

Se argumentó anteriormente que la playa es ese espacio donde limitan ambos mundos: el marino y el terrestre; pero, trascendiendo aún más su significación, se puede demarcar como límite entre lo interior y lo exterior al ser, entre la mismidad y la otredad. Todo límite es una tensión. Entonces, si se reúnen ambos elementos y se asocian con el conflicto 'fe'-'destino', en donde aquella ocupa un espacio en la psique del ser (representado por el agua) y donde este, un espacio de manifestación concreto (lo terrestre), la angustia de todo sujeto ante la posibilidad de verse desamparado de las estructuras dogmáticas que lo definen y ante la posibilidad de verse amenazado por acontecimientos predestinados se intensifica en mayor dramatismo ontológico y existencial.

El puente como artificio permite esa transitoriedad entre lo aparente y lo real (Chevalier y Gheerbrant 1988), entre 'fe' y descreimiento, entre dolor y misterio; entre lo que fue creído y lo que es ahora creíble. En la pintura, el puente parece unir tierra y agua. Por lo tanto, el ser tiene acceso a los planos de conciencia, materiales o abstractos, que le permiten existir y lo limitan a su condición de unidad subjetiva y social a la vez, inclusive en el plano inconsciente.

En el cuadro, no se llega a definir el principio ni el final del puente, solo se aclararán estos a partir del rumbo que el sujeto representado emprenda sobre él, la trayectoria ejecutada desde una dirección hasta otra es inversamente anulada. Es decir, cuando el sujeto representado se dirige desde una hasta otra dirección sobre el puente, esta trayectoria se ve anulada (el 
desplazamiento es igual a cero, aunque la distancia se haya duplicado), pues se llega a un mismo punto cero de partida. En consecuencia, el puente carece de final y principio; él es, simplemente, simulando un ciclo inevitable. Dicho ciclo es sugerido a partir de los elementos sintácticos reiterados en el primer y último verso de ambos poemas ("Hay golpes en la vida tan fuertes [...] Yo no sé!"). Los 'golpes' son un ciclo que se anulan y se reafirman a sí mismos constantemente en la vida del sujeto representado y los sujetos líricos. Es la naturaleza del ser humano: un ciclo constante de presencia, búsqueda y trascendencia.

\subsubsection{Son pocos; pero son...}

No se pretende agotar las relaciones intertextuales, sino más bien sugerir algunas de ellas. Nótese en todo momento que los mismos gramas que permiten la generación del sentido profundo del texto posibilitan el establecimiento de diversos vínculos con otros textos, pues las virtualidades semánticas proporcionadas por los niveles de sugerencia en cada texto estético llevan al lector a sospechar marcas reminiscentes en textos homólogos.

\section{Hay golpes en la vida, tan fuertes... ¡Yo sí sé!}

Con base en los elementos analizados a través de los dos textos poéticos desde la instancia intratextual y de ambos textos con el texto pictórico de Munch desde el nivel intertextual, se observa que:

a. Desde los gramas fonéticos, la presencia de fonemas oclusivos sordos y sonoros genera una cadencia en torno al sema-lexema 'golpes', con lo cual se intensifica su carácter dramático; los fonemas fricativos como /f/ permiten desarrollar una fluidez en el ritmo del verso hasta sugerir una revelación incierta del dolor expreso y de la liberación de los significados del sema-lexema principal; los fonemas sibilantes, en su mayoría /s/, generan una ambientalidad envolvente alrededor de las imágenes poéticas más intensas y dramáticas del poema; los segmentos vocálicos /a/ y /o/ preparan antesalas fonéticas acentuadas para la llegada de imágenes poéticas cada vez más fuertes. Asimismo, cada una de estas vocales revela un nuevo sema ligado al principal: 'alma' y 'ojos', respectivamente. Los elementos fonéticos y fonológicos resultan semejantes en su manifestación a lo largo de ambos textos. No se encuentran cambios notorios entre ambas versiones del poema.

b. Desde los gramas sémicos, la realización perifrástica en torno al sema-lexema principal ('golpes') tiende a intensificarse enfática y dramáticamente a medida que el poema se desarrolla. La causa y los actos consecuentes del dolor resultan totalmente enigmáticos para el ser desde el plano de la conciencia y lo fenomenológico de su realidad. El sufrimiento humano implica un enfrentamiento del ser tanto con su mismidad (espacio interior) como con su otredad (espacio exterior) a lo largo de los momentos de crisis en la vida. La realización perifrástica del sema-lexema principal involucra, al sujeto lírico y al lector convocado por la otredad del texto, a niveles físicos, psicológico-emotivos y metafísicos donde toman cabida las causas y consecuencias del dolor ontológico y existencial. Los elementos sémicos resultan semejantes en ambas versiones del texto poético. 
c. Desde los gramas sintagmáticos, la reiteración de los modelos y estructuras morfosintácticas predominantes corresponden a complementos adnominales, oraciones copulativas, oraciones subordinadas de relativo y frases explicativas, las cuales establecen dependencias fuertes entre los semas perifrásticos y el semalexema principal. Las oraciones copulativas asocian terminantemente la existencia y la limitación ontológica del ser ante el dolor por medio del verbo copulativo 'son'. Al ser humano, como sujeto nominal, desinencial o tácito, se le atribuye dramática e inevitablemente, por medio de los complementos predicativos (constituidos por semas perifrásticos), todo el ímpetu del sema-lexema principal; es decir, los 'golpes' significativamente vitales. Las mayores diferencias entre "Los heraldos negros" versión primera y su versión oficial se encuentran determinadas por los sintagmas involucrados. Las alteraciones o cambios entre una y otra versión ocurren en el proceso de corrección, creatividad e intensificación de las imágenes poéticas. Estilo y dramatismo se relacionan intrínsecamente. La corriente de conciencia del poema toma rumbos diferentes en ambos textos, pero conservando aún el sema-lexema principal.

d. Desde las relaciones y elementos intertextuales posibles, los gramas sémicos y sintagmáticos permiten mayores relaciones entre los textos. El sema-lexema principal ('golpes') se encuentra reminiscente en la plurisignificación de los tres textos estéticos, a través de sus realizaciones perifrásticas.

\section{Notas}

1. De acuerdo con Fernández: "La reticencia es la figura que deja una frase sin acabar, sea porque se sobrentiende la idea [...], sea por manifestaciones anímicas [...] la retinencia se indica por los puntos suspensivos en la escritura y por el tono de voz en la conversación o discurso [...] Se hace uso de la reticencia cuando se quiere hacer sospechar una cosa sin decirla expresamente" (1972: 91).

\section{Bibliografía}

Amoretti, María. 1992. Diccionario de términos asociados en teoría literaria. San José: Editorial de la Universidad de Costa Rica.

Chavarría, Gabriela. 1988. El discurso sobre la identidad latinoamericana en el discurso crítica en torno a Los heraldos negros. Tesis de licenciatura: Universidad de Costa Rica.

Chevalier, Jean. y Alain Gheerbrant. 1988. Diccionario de los símbolos. Barcelona: Herder.

Chirinos, Eduardo. 1988. "Vallejo en la poesía peruana (1950-1970)". Cuadernos Hispanoamericanos, 454-455 (1): 167-180.

Faúndez, Edson. 2009. “Los heraldos negros: Un «verso gris» seducido por la dinámica de los trayectos”. América sin nombre, 13-14: 123-132.

Fernández, Pelayo. 1972. Estilística. Madrid: Porrúa. 
Ferrari, Americo. 1988. "Vallejo, Vallejos: Vida y obra”. Ínsula, 501: 28-29.

1997. César Vallejo. Obra poética. San José: ALLCA XX.

Juliá, Mercedes. 1988. "César Vallejo y Edvard Munch”. Cuadernos Hispanoamericanos, 454-455: 97-103.

Ly, Nadine. 1988. “La poética de Vallejo o la palabra inteligente”. Ínsula, 501: 15-17.

Martínez, Francisco. 1988. "Referencias bíblico-religiosas en la poesía de César Vallejo y su función desde una perspectiva crítica". Cuadernos Hispanoamericanos, 456-457: 641-715.

Mazzotti, José. 1999. "Modernismo, postmodernismo y modernidad conflictiva en el primer Vallejo". Códice. Revista de Poesía y Poéticas, 1: 23-31.

Melis, Antonio. 1988. "Hacia la alteridad de César Vallejo”. Ínsula, 501: 17-18.

Monguió, Luis. 1954. La poesía postmodernista peruana. Berkeley y México: University California Press y Fondo de Cultura Económica.

Montiel, Luis. 1988. "El camino hacia el hombre desde el dolor y la muerte". Cuadernos Hispanoamericanos, 456-457: 803-811.

Munch, Edvard. 1893. El grito. http://www.ucm.es/info/echi1/imagen/pint/gritomunch.htm

Ortega, José. 1988. "Aproximación a la dialéctica de la religión en la poesía de Vallejo". Cuadernos Hispanoamericanos, 456-457: 731-737.

Oviedo, José. 1988. "Contextos de Los heraldos negros". Cuadernos Hispanoamericanos 1, 454-455: 247-262.

1990. "Contextos de Los heraldos negros". Cuadernos Hispanoamericanos 1, 454-57: 248-256.

Paoli, Roberto. 1988. “¡Inolvidable cholo!, César Vallejo (1938-1988)”. Ínsula, 501: 11-13.

Real Academia Española. 2010. Nueva gramática de la lengua española: Manual. España: Espasa Libros.

2011. Ortografía de la lengua española. México: Planeta.

Sarduy, Severo. 1977. "El barroco y el neobarroco”. En: Fernández, C. América Latina en su literatura. México: Siglo veintiuno. 
Vallejo, César. 1972. Los heraldos negros. Buenos Aires: Losada.

Vélez, Julio. 1988. "Muerte y vida: constantes del tiempo vallejiano". Cuadernos Hispanoamericanos, 456-457: 839-851.

Yurkievich, Saúl. 1988. “El soterrado y vivo hervor”. Ínsula, 501: 13-15. 
